\title{
Text and Terror: How Boko-Haram Terrifies Nigerians Using 'Ordinary' Words
}

\author{
Omolade Bamigboye \\ douglas_e4@yahoo.com,omolade.bamigboye@eksu.edu.ng \\ Department of English and Literary Studies, \\ Ekiti State University, Ado-Ekiti, Ekiti State, NIGERIA
}

\begin{abstract}
This paper investigates how Boko-Haram uses language to create terror in the minds of Nigerians. Boko-Haram, an Islamic terrorist organisation based in Nigeria and some other West African countries, periodically releases videos in which threats are made to the public. These videos are then transcribed into text by major news media all over the world. The thesis of the paper is if seemingly innocuous expressions are interpreted with fear as a result of who utters them. After a thorough study of possible theoretical approaches, the cognitive stylistics approach was deemed most suited for the present work. This is because the approach sees readers as 'actively involved in the process of meaning-making', Jeffries and McIntyre (2010: 127). Using the Schema Theory as conceptual framework, I argue that the readers of these statements interpret same with the residual knowledge they have of the world. Schema Theory submits that certain elements of background knowledge are superimposed on the text by the reader in creating a world (scenario) while reading the text. The findings reveal that the source of a text goes a long way in determining how it is digested by readers. Also, readers make sense of texts based not just on what is read, but the surrounding information they mentally impose on it.
\end{abstract}

Keywords: text, terror, Schema-theory, Boko-Haram.

\section{Introduction}

In contemporary world affairs, terrorism is a major topic that continues to dominate the news and generate actions and reactions from the various spectrums of perspectives that are directly or indirectly involved in its execution and on its social, political and religious impacts. Major news outlets like CNN and BBC devote much airtime and content to stories that border on terrorism because of the way it has shaped world politics, governmental policies and directions as well as the global reach of its practitioners' despicable activities. In all, the composition of terrorist agenda (whether religious, nationalistic, psychological, linguistic) has attracted academic investigation that hope to expose their modus operandi, structural arrangement, social reach and linguistic idiosyncrasies with a view to understanding and curtailing their activities thereby promoting peace in subcontinents and the world in general, (Thompson, 2012; Barkindo, 2013; Eveslage, 2013)

There are mainly two types of videos or press releases usually made by most terrorists. One type is made before any major or minor attack whereas the other is made after such an attack might have already taken place. That pre-attack video or text talks of anticipatory violence and its potential victims while the post-attack ones are usually done to take responsibility and gloat over the incident. Experts claim that most terrorist attacks are results of well planned and painstakingly organised efforts that usually leave nothing out. They plan the target of the attack, the soldiers who will execute it and the message to be sent out. The content and tone of this message and how it is understood by the reader is the preoccupation of this paper. 
When terrorists use language, they consciously choose lexical elements, and linguistic structures that will most suitably convey their intent in the most effective manner. Other sociolinguistic variables like accent, intonation and dialect are also taken into consideration; this with the knowledge that every minute details of the video or statement will be analysed forensically by the experts in the various fields of antiterror endeavours. The Jama'atu Ahlus Sunnah Lidda Awati Wal Jihad, popularly known as Boko-Haram (Western education is $\sin$ ), is one of such terrorist organisations. They routinely send out videos and statements that detail their trajectory of unleashing immeasurable violence on Nigerians, especially in the North-Eastern part of the country. Sometimes originally encoded in Hausa, a regional language in the north of Nigeria; the texts are now redacted and the video subtitled in English for proper dissemination to all Nigerians.

Unusually, they may threaten their targets and members of the public with strong words that emit rage. However, most of the releases are replete with subtle and coded messages that often tend to project the terrorists as fighting a just cause. In their bid to stop the spread of western education, especially for the girl child, they tend to proselytise and admonish the public on what they believe is the position of their god on such issues. Abetted by bigoted local priests and corrupt politicians, they couch the veiled threats in expressions that are coloured with sanctimonious offerings and 'moral' values which resonate with the existential challenges of the natives.

\section{Methodology}

The data were sourced from an online archive of the press releases of Boko-Haram. This web page reads: https://www. researchgate.net/publication/258469765.

The documents are dated between 2011 and 2014. Of the total items available, three were purposively selected and serve as the data. They researcher is convinced they have the most relevant materials for this academic undertaking. Excerpts from the three were then subjected to analysis, using the aforementioned schema theory as conceptual framework. Particular words and larger grammatical constructs serve as basis for the analysis of reader-oriented interpretations of the compositions released by Boko-Haram. A detailed overview of Schema Theory will be given presently.

\section{‘Ordinary’ Words}

(We are in Kano, ready to start. We are your friends. We are your saviours.)

The excerpt above ordinarily betrays convivial emotion that is based on warmth and redemption. It shows no malevolence; at least at face level. This is what we refer to, in this context, as 'ordinary words'. The way we use language, scholars of old had argued, says a lot about us. Apart from the individual sociolinguistic variables (like accent, intonation, diction, the pitch of voice and so on) that are embedded in the way a particular person uses language, other generic inferences like mutual contextual beliefs, shared ideologies and socio-cultural norms may be betrayed in an individual's linguistic output. This is to say that language is not used in a vacuum; that is, there are some extra-linguistic factors that are superimposed on language that eventually accentuates the establishment of meaning, even beyond what has been said. In other words, the user of language carries with him a commonality of both linguistic and paralinguistic elements that he shares with members of his immediate speech community. All these factors he unconsciously brings to bear on his meaning-making linguistic activities as the day goes by.

In any communication event, the language user among other things tends to choose the words that will most effectively convey his thoughts to his audience. Indeed, the need to be understood by the greatest majority prompts many a public speaker to pick, use and deliberately employ words and expressions that bear the hallmark of everyday usage. A certain factor that guides 
user diction is the need not to be misunderstood or for one's original linguistic intentions not to be misconstrued. Therefore, the average communicator gauges his audience and appropriately deploys linguistic elements from his vocabulary to suit his present needs.

For any organisation or group that seeks mass appeal, the use of language is advisedly simple and couched with less elegance but more clarity, as far as content is concerned. Esoteric and unnecessarily grandiloquent words that may derail the communication process are avoided.

Seemingly innocuous words are interpreted with fear as a result of who utters them. This is the thesis of this particular paper. Although the relationship between text and context has been established long ago, a new vista is however opened on the way they connect as far as terrorism is concerned. Modern religious terrorists, says Davieson (2014), often use subtle means (language) to threaten their targets. They avoid overtly violent adjectives and verbs in their attempt to portray themselves as moral agents/warriors of God fighting a just cause. Nigerians who read and listen to the text and broadcasts respectively react the way they do because they share both terrestrial and knowledge-based context with the Boko-Haram terrorists. Due to the carnage that has been visited on the people for a long time, any video or statement released by this terror group is bound to elicit grave concern and fear in the minds of the listeners and hearers respectively.

The agenda of the group, that is, spreading fear in the minds of the populace, is, however, not mitigated or reduced by the claim to subtleties. As a matter of fact, this style may even lure otherwise intelligent and patriotic individuals into believing in their evil gospel. The sophisticated manner of language use actually betrays the educational level of the terrorists.

\section{Cognitive Stylistics}

Cognitive stylisticians base their thesis on the perceived subjective interpretation given to particular texts by different readers, (Semino and Culpeper 2002, Stockwell 2002, Gavins 2003). This branch of stylistics deals with the mental processes involved in meaning-making, while reading. Although a branch of stylistics equally involved in the linguistic interpretation of texts, it goes further to incorporate the role of the reader into this task. When we read, say scholars in this particular field, we build mental images and create scenarios that sort of breed life into words. Cognitive stylistics, in the words of West in (2011, p. 239):

\begin{abstract}
Moves beyond stylistics in its insistence that the linguistic phenomenal identified in a literary text have psychological reality; in other words, that they do not exist independently of the reader, and in particular of the cognitive processes-for example, attention, expectation, memory, categorisation, analogical reasoningthat the reader inevitably and unconsciously brings into the text.
\end{abstract}

The view above itemises the mental processes involved in getting perspectives on authorial outputs. These mental processes are done unconsciously and systematically, with a corresponding regularity that is commensurate with the frequency of reading. In other words, the more familiar we are with texts, the better our ability to conceptualise the images we find in them. This aligns with Nakane's (2007) view that says language processing speed is also related to the linguistic capacity of an individual. This position is also strengthened by Stockwell (2009) who argues for the significance of 'texture', which he loosely describes as the interplay between words on the page and a reader's cognitive mechanism.

Jeffries and McIntyre (2010) also claim that the phenomenon of social cum individual prejudice or personal insights bearing down on textual understanding cuts across both the literary and non-literary 
spectra; although, Cook (1994, p. 10) argues that literary texts are distinguished from non-literary texts by their capacity to induce schema refreshment'. In their seminal dissection of the subject, Jeffries and McIntyre (2010, p. 126) enumerate the schema theory, concepts of figure and ground and the cognitive metaphor theory as ideal tools in the practical realisation of the subject matter in cognitive stylistics. While the schema theory focuses on how we package world knowledge and use it in the interpretation of texts', figure and ground determine how residual information influence highlighting in space and the cognitive metaphor theory is concerned with using schematic knowledge to structure our worldviews. For the purpose of this paper therefore, we shall examine the schema theory and attempt to apply it to the collated texts under stylistic consideration.

\section{The Schema Theory}

Textual triggers are words that ignite or spur particular scenarios in the minds of the conscientious reader while engaged in the act of reading. In the same vein, schema refers to an element of background knowledge about a particular aspect of the world, Jeffries and McIntyre (2010: 127). Human experiences play a vital role in the development of a schema. For example, Culpeper and McIntyre (2010) use the job interview to illustrate what an individual's schema of such a topic read from a text could be. A corporate job interview will most likely create a scenario of men in suits and formality in language whereas, a job interview for manual labourers at a construction site may be less formal. It is these scenarios that are created from the texts that betray a reader's level of sophistication, education, exposure and so on.

Also, Rumelhart (1980) argues that schemas are not static. That is as an average reader's experience accrues and the vocabulary expands, the schemas being built while reading also enjoy the addition of such discovery and knowledge. Schank and Abelson (1977) propose their famous four headers-that is the textual cues that relate to the schema in question- which they argue accounts for all instances of mental scenebuilding while reading. The four triggers are further explained by Jeffries and McIntyre (2010, p. 129) thus:

i. Precondition headers: these account for a precondition that will necessitate the creation of a particular scenario. The sentence 'Dan was feeling ill' is used to give a precondition that could trigger a doctor/patient scenario, for example.

ii. Instrumental headers: refer to actions that may lead to a particular script being initiated. For instance, in 'Dan entered the doctor's office', the act of 'entering' may be the trigger for a doctor/patient encounter.

iii. Locale headers: these are references to locations where the scene in question may be activated. If a sentence like 'The doctor's surgery was a cold and forbidding place' starts a text, for example, we might expect that it could provide a locale for a doctor/patient interview.

iv. Internal conceptualisation headers: this kind of headers is actually derived from the roles and actions of characters in the text. The given example here is that of the sentence 'The doctor asked Dan how he was feeling'. Here, a role (the doctor) and an action (asking how the patient feels) are likely to instantiate the scenario.

These four headers are by no means compulsorily evident in all texts, as some compositions may reflect just about two of them. Also, the background knowledge of the world which is triggered by these headers may be inadequate in some readers. This owes to their level of exposure and the size of their vocabulary reservoir which may impede the activation and sustenance of particular schematic scenarios in the process of reading. According to Fowler (1986), such group of readers is 'underlexicalised'. 


\section{Results and Discussion}

\section{Excerpt 1}

Jan 11, 2012, page 2. We would confront [soldiers] squarely to protect our brothers. We have stopped everything apart from saying we should stay on the path of truth and peace and live right in the sight of God. There, we will have peace and that is what we have been preaching and because of that they said we should be silenced. We decided to defend ourselves and God has said if you follow him, he will give you strength! That is why Jonathan, you should know that this is beyond your power. It is not our doing but that of God. It is beyond you. Anybody that says he will not follow God, even if he loves us, God has not said we should love such a person. God has said we should show such person the right path and embrace such person! You Christians should know that Jesus is a servant and prophet of God. He is not the son of God. This religion of Christianity you are practicing not a religion of Godit is paganism. God frowns at it. What you are practicing is not religion. This path we're taking is God's path!

(Culled from https://www.researchgate .net/publication/258469765, p.2)

Precondition header: The word 'confront' in the first sentence gives the precondition that a battle was imminent between the addressers and the addressee (the Boko-Haram insurgents and the Nigerian military). Also, 'stopped everything' and 'follow God' may trigger the spectacle of otherwise enterprising and gainfully employed men abandoning their homes and means of livelihood, to take up terrorism and reside in the vast and unforgiving Sambisa forest.

Instrumental header: When the terrorists claim to 'defend ourselves', this triggers the schema of armed resistance against constituted authorities. The average reader familiar with the reputation of BokoHaram most likely will translate this to mean a brutal bloodbath. 'Silenced', in line four carries a deeper interpretation of a massacre or extra-judicial killings, a trait that indeed was once ascribed to some Nigerian soldiers. 'Love' here transcends the care for the wellbeing and happiness of others but the strict adherence to their perverted interpretation of the Quran. Since 'God' has not said they should 'love' anyone who shares a contrary opinion with them, the implication of this is already laid in the imagination of the average reader as a complete annihilation of the person.

Locale header: 'Jonathan', the name of the then Nigerian President, triggers the schema of Abuja, the nation's capital and seat of power. The use of the name shifts the reader's mind the location of both legitimate and pro-citizens power as opposed to the location of the terrorists. Again, the words 'Christians' and 'Christianity' project the images of church worship as different from Islamic way of worship in the mosques. This may actually trigger an unfortunate mental scenario of a religious war.

Internal conceptualisation headers: If God indeed 'frowns' at the act of 'practicing' Christianity, then the role erroneously given to Him in the text comes to the reader's mind as completely wrong. Also, 'path' in 'This path we are taking is God's path!' mentally links the purported role of 'God' with the dastardly acts of the terrorists. Inadvertently, one can infer the terrorists' duplicitously pious admonitions as attempts to proselytise evil.

\section{Excerpt 2}

In the name of Allah, the most beneficent and merciful.

Jan 21, 2013. We are the ones that they address with the prohibited name Boko Haram, when our name is Jama'atu Ahlus Sunnah Lidda Awati Wal Jihad (Congregation of Followers of the Prophet Involved in the Call to Islam and Religious Struggle) This message is to the people of Kano. You should know that the security (Police) in Kano are using tricks in arresting our people, that is they tell people in different neighbourhoods that they are arresting thieves or armed 
robbers - you should know that it is our people that they are arresting. (1: security police)We want peace and we do not have any intention of touching any people of this town if they do not touch us. Because our war is with the Government that is fighting Islam with the Christian Association of Nigeria (CAN) that are killing Muslims even eating their flesh and those who helped them to fight us even if they are Muslims. (1:government and 1: Christian Association of Nigeria) Anyone who is instrumental to the arrest of our members is assured that their own is coming. (2: anyone)

(Culled from https://www.researchgate .net/publication/258469765, p. 3)

Precondition header: In the second sentence, 'We are the ones', automatically makes the reader recall the residual information that are stored in the mental resources of his/her own mind, concerning Boko-Haram. The fact that they prefer a certain name to Boko-Haram preconditions the attitude of intransigence. Already, the reader of this excerpt is cognitively expectant of the usual things to expect from the organisation.

Locale header: This particular information is for the people of Kano, a sprawling megalopolis in the West of Northern Nigeria. The reader's mental image of Kano is thus triggered; as well as the potential havoc Boko-Haram may wreak. Kano is mentioned twice, a repetition perhaps orchestrated by the need to be unambiguous as to the target of their next nefarious activity.

Instrumental header: 'Should know', 'tell people', 'arresting thieves and robbers' all textually and mentally portray the gathering of violent storms. These actions, by the contextual premises relayed in the excerpt, triggers the anticipation of peculiar Boko-Haram violence in the city of Kano.

Internal conceptualisation header: This is most evident in the last sentence of the excerpt 'Anyone who is instrumental to the arrest of our members is assured that their own is coming.' Boko-Haram's subtle threat in embedded in the word 'own'--- that is, the killing of perceived informers who relay information about them to the authorities. Also, not 'touching' people who do not 'touch us' amply belies the suggested harm that would happen to those who engage the militants in any way.

\section{Excerpt 3}

September 30, 2014

This short message is to traditional rulers who have been conspiring against us, that they have no hidden places for conspiring against our commitment and worship to Allah. They have entered our way and have no hidden places anymore, this they should know. Just wait and see what we will do. We did not even talk because of peace and now they have continued capturing our women, this week about seven women were captured and we don't even know where they are, but they are being held by infidel enemies of Allah. In fact, they are even having sex with one of them. Allah, Allah, see us and what we are going through. It is in one place that they are holding seven women, in other places they are more than that. Only Allah knows the actual number of our women being held, women who are married in accordance with Islamic law. "Since you are now holding our women, (laugh) just wait and see what will happen to your own women. Just wait and see what will happen to your own wives according to Shariah law, (laugh) just wait and see if it is sweet and convenient for you. (3: wives of government officials) "SSS rubbish, Shekau on your neck, SSS you will see it. (Culled from https://www.researchgate .net/publication/258469765, p. 20)

Precondition header: The claimed conspiracy of traditional rulers preconditions there is a conflict of interests between the highly revered northern Emirs and the Islamic insurgents. The reader is introduced into this charged interface by the use of the word 'conspiring', a rather ineffective euphemism for open denial of 
support and hostility. The Emirs are often united in their condemnation of the evil that are routinely perpetrated by the terrorist sect. Any reader familiar with this knowledge will easily discern the image of the Emirs who are unfazed by imminent danger.

Instrumental header: Some words in the text above conjure images of violent confrontations between the terrorists and law enforcement. 'They', 'capture', and 'holding' all portray images of detention amidst resistance, resulting aftermaths of the frequent skirmishes between both parties. They also lead to schemata of how civilian detainees are maltreated in various detention centres across the nation, let alone known terrorists.

Locale header: "This week", 'in one place' and 'other places' initial the scenario of the location of arrested terrorists and their accomplices. The mental representations of Nigerian prisons are triggered as a result of these aforementioned words. The images are most likely to be unpleasant, which is the desired effect the terrorist authors wish to have on their listener/reader.

Internal conceptualisation headers: The sentence 'Just wait and see what we will do' would have been interpreted differently and the picturesque effect on the mind altered had it been written by anyone else. However, because it is from Boko-Haram, the average reader will not fail to decipher the threat of violence embedded in it. The role given to Allah of 'knowing' the number of female captives and the subtle thereat in 'you will see it' both attest to the reputation of Boko-Haram as a violent organisation that pretends to do God's will. In the excerpt, adjectives that literally espouse or conjure violence are deliberately avoided.

Taking a cursory look at the choice of words in our data, one can conclude that the author(s) deliberately choose words that will best transmit authorial intents. Verbs with veiled meanings and subdued violent impact like defend, touch and are consciously used instead of more graphic and vivid alternatives like arm, injure and kill respectively. Their usage is probably informed by a careful attempt at projecting themselves as faithfuls who are moderate, decent and fighting a just cause.

The word 'peace' occurs four times in the three excerpts: excerpt one, lines 2 and 3 ; excerpt 2, line7 and excerpt 3, line 4 respectively. This is in contrast to war which occurs only once in line 8 of the second excerpt. This is highly significant because it belies the attempt to showcase to the world that they are peace-loving people. It reinforces the researcher's argument that the insurgents deliberately couch their language in pacifistic mould to deceive the public into having sympathy for them and subsequently embracing their selfish and evil doctrinal agenda.

Also, the four identified headers are represented by particular words, phrases and sentences which trigger mental activities of painting scenarios in the minds of the reader. This is a seamless traffic of rational progression in the business of textual meaning-making. The four headers correspond to one another to make meaning a wholesome and systematically organised cognitive experience. In each of the three excerpts studied, it is evident that the presence of these pointers helps in no small way in the total understanding and appreciation of the contents of the texts.

Finally, although the Schema theory has been able to aptly demonstrate the intricate value of reader participation in meaning making, it is by no means the only way this could be established. Fellow researcher can investigate further, not only on the linguistic preferences and idiosyncrasies of the BokoHaram sect, but on the importance of the reader in the overall business of textual comprehension.

\section{Conclusion}

From the analysis above, the argument that Boko-Haram, although a bloodthirsty jihadist group that inflicts pain on innocents, somehow uses innocuous and common, 
everyday expressions to create fear in the minds of Nigerians has been reinforced. Also, it should be noted that the cognitive advancement or otherwise of the reader notwithstanding, texts are read and meaning is made as a result of the projection of meaning from the text and the construction of same by the readers themselves. Meaning making is, thus, an exercise that juxtaposes the inferences from the text with the world knowledge of the reader. For example, the expression "You are in our minds" may connote a sinister motive, when read and understood against the heinous acts of terror Boko-Haram regularly propagates, especially in the Northern provinces of Nigeria.

In the three excerpts studied and analysed in this paper, it is submitted that there are interplays between the individual texts and particular readers. This, most likely, occurs at any level of human development. Whereas the level of comprehension increases correspondingly to the level of education and world exposure, this process, however, takes place anytime a conscientious literate person picks up a composition to read. The idea that something happens during the reading process that serves as the bedrock of textual understanding is, thus, an interesting submission.

\section{References}

Barkindo, A. (2013). 'Join the Caravan: The Ideology of Political Authority in Islam from Ibn Taymiyya to Boko Haram in North-Eastern Nigeria'. Perspectives on Terrorism, 7,(3), pp. 30-43. Retrieved from http:www.terrorismanalysts. com/pt/index/php/pot/article/view/2 66

Cook, G. (1994) Discourse and Literature: The Interplay of Form and Mind. Oxford: Oxford University Press.
Culpeper, J. And McIntyre, D. (2010). 'Activity Types and Characterisation in Dramatic Discourse'. In Schneider, R., Jannidis, F. and Eder, J. (Eds.) Characters In Fictional Worlds: Interdisciplinary Perspectives. Berlin: De Gruyter.

Davieson, A. (2014). Boko-Haram and Its Suicide Squad: the Confession of a Jihadist. Lexington, KY: CreateSpace Independent Publishing Platform.

Eveslage, B. (2013). Clarifying Boko Haram's Transnational Intentions Using Content Analysis of Public Statements. Perspectives on Terrorism, 7(5), 49-76. Retrieved from http://www.terroris manalysts.com/pt/index.php/pot/articl e/view/291

Fowler, R. (1986). Linguistic Criticism. Oxford: Blackwell.

Gavins, J. (2003). 'Too Much Blague? An Exploration of the Text Worlds of Donald Barthelme's Snow White'. In Gavins, J. \& Steen, G. (Eds.) Cognitive poetics in practice, (pp. 129-44). London: Routledge.

Jeffries, L. \& McIntyre, D. (2010). Stylistics. Cambridge: Cambridge University Press.

Nakane, I. (2007). Silence in Intercultural Communication: Perceptions and Performance. Amsterdam/Philadelphia: John Benjamins Company.

Rumelhart, D. E. (1980). 'Schemata: The Building Blocks of Cognition'. In Siro, R. J, Bruce, B. C., and Brewer, W. F., (Eds.) Theoretical issues in reading comprehension, (pp. 38-58). Hillsdale, NJ: Erlbaum.

Schank, R. C. and Abelson, R. (1977). Scripts, Plans, Goals and Understanding. Hillsdale, .NJ: Lawrence Erlbaum Associates.

Semino, E. \& Culpeper, J. (Eds.) (2002) Cognitive Stylistics: Language and 
Cognition in Text Analysis. Amsterdam: John Benjamins.

Stockwell, P. (2002). Cognitive Poetics: An Introduction. London: Routledge.

Stockwell, P. (2009). Texture: A Cognitive Aesthetics of Reading. Edinburgh: Edinburgh University Press.

Thompson, V. (2012). Boko Haram and Islamic Fundamentalism in Nigeria. Global Security Studies. 3(3), pp. 46-60.

West, D. (2011). 'Teaching Cognitive Stylistics'. In Jeffries, J. \& McIntyre, D. (Eds.) Teaching Stylistics, (pp. 239-54). Hampshire: Palgrave Macmillan

\section{Webography}

Boko Haram Public Statements Full List. Retrieved from https://www.researchgate.net/publica tion/258469765 